\title{
Menelaah Kembali Peran Bappenas sebagai Lembaga Think Tank Pemerintah
}

\author{
Muhyiddin ${ }^{1}$ \\ Kementerian Perencanaan Pembangunan Nasional/BAPPENAS - Indonesia
}

\begin{abstract}
Abstraksi
Studi ini mencoba mengelaborasi model kelembagaan think tank pemerintah yang sesuai dengan Indonesia. Pendekatan studi ini kualitatif dengan melakukan studi best practices di Korea Selatan dan India yang mempunyai lembaga think tank yang berasal dari institusi perencanaan, yaitu KDI dan NITI Aayog. Adaptasi model KDI dan NITI Aayog diperlukan untuk merevitalisasi fungsi think tank yang sudah ada pada Bappenas. Kelembagaan think tank ini akan menjadi jembatan antara penelitian dan kebijakan (bridging research to policy) dan jembatan ilmu pengetahuan kepada kekuasaan (bridging knowledge to power). Kompleksitas permasalahan pembangunan menjadi tantangan pemerintah untuk dikelola dan diatasi berdasarkan ilmu pengetahuan yang bersumber dari penelitian akademis. Lembaga think tank harus dapat merumuskan bagaimana ilmu pengetahuan tersebut ditransformasikan menjadi riset kebijakan sehingga dihasilkan solusi kebijakan yang teruji.
\end{abstract}

Kata Kunci: bappenas, think tank

Muhyiddin adalah Perencana Madya pada Pusat Analisis Kebijakan dan Kinerja - Kementerian Perencanaan Pembangunan Nasional/BAPPENAS. Penulis juga sebagai Ketua Editor Jurnal Perencanaan Pembangunan. Email address: udyn@bappenas.go.id. 


\title{
Menelaah Kembali Peran Bappenas sebagai Lembaga Think Tank Pemerintah
}

\author{
Muhyiddin
}

\section{Pendahuluan}

Kementerian PPN/Bappenas menurut Perpres nomor 20 tahun 2016 memiliki posisi di kabinet sebagai lembaga pemikir pembangunan, dalam istilah populernya sebagai think tank, yaitu yang bertugas merumuskan kebijakan, menyusun rencana pembangunan, dan mengkoordinasikan pencapaian tujuan berbangsa dan bernegara sekaligus melakukan evaluasi atas pencapaian upayaupaya pembangunan tersebut. Sedangkan berdasarkan Undang-Undang No. 25 Tahun 2004 tentang Sistim Perencanaan Pembangunan Nasional, Bappenas memiliki kewenangan untuk melakukan perumusan kebijakan nasional dan melakukan proses perencanaan pembangunan.

Lembaga think tank pemerintah pada dasarnya berfungsi sebagai jembatan antara ilmu pengetahuan dan kebijakan pemerintah. Kompleksitas permasalahan pembangunan yang terus meningkat menjadi tantangan pemerintah untuk dikelola dan diatasi berdasarkan ilmu pengetahuan. Lembaga think tank pemerintah mempunyai tugas utama dalam merumuskan bagaimana ilmu pengetahuan tersebut ditransformasikan melalui riset kebijakan sehingga dihasilkan rekomendasi kebijakan yang teruji.

Bicara kesuksesan lembaga think tank pemerintah, maka kisah sukses pengalaman Korea Selatan patut untuk diperhatikan, mengingat negara ini dapat bertransformasi dengan capaian-capaian yang dapat terekam dengan baik, dimana tadinya tergolong sebagai negara miskin di tahun 1960an lalu menjadi negara maju pada tahun 1980an dan terus melaju pesat sebagai salah satu ikon keajaiban perekonomian dunia.

Lalu bagaimana praktik di Indonesia tentang fungsi jembatan ilmu pengetahuan ke kebijakan pemerintah akan coba dielaborasi dalam studi ini. Struktur pemerintah pusat sendiri menyebut fungsi think tank ada pada Kementerian Perencanaan Pembangunan Nasional/Badan Perencanaan Pembangunan Nasional (Bappenas), sedangkan di kementerian ada di lembaga penelitian dan pengembangan dengan nama spesifik Balitbang (Badan Penelitian dan Pengembangan).

Kajian ini mencoba mengelaborasi sebuah studi kualitatif dengan pendekatan komparatif, pengalaman terbaik (best practices) dari lembaga-lembaga think tank pemerintah di Korea Selatan dan India. Bagaimana lembaga think tank di Indonesia dapat mereplikasi praktik terbaik tersebut menjadi fokus bahasan pada studi ini, sehingga dapat menawarkan sebuah model lembaga yang menjadi jembatan antara penelitian menuju kebijakan (bridging research to policy) di pemerintahan Indonesia. 


\section{Tujuan dan Metodologi}

Dalam konteks kebijakan publik dan perencanaan pembangunan, peran lembaga think tank pemerintah sangat penting untuk mendukung lahirnya kebijakan-kebijakan publik yang berkualitas dan rencana pembangunan yang realistis, terukur dan dapat diimplementasikan.

Tujuan kajian ini adalah merumuskan model lembaga think tank di pemerintah Indonesia, yang diharapkan menjadi jembatan yang berfungsi sebagai 'bridging knowledge to policy' dimana fungsinya adalah menyusun kebijakan pembangunan berdasarkan ilmu pengetahuan (knowledge based policy).

Metodologi yang dilakukan dalam kajian ini menggunakan pendekatan studi kualitatif dengan menguraikan praktik-praktik terbaik (best practices) obyek sejenis di Korea Selatan dan India melalui studi pustaka/literature (desk study).

Korea Selatan dan India dipilih karena kedua lembaga think tank pemerintah negara tersebut sama-sama lahir dari institusi perencanaan. Korea Development Institute lahir dari institusi Economic Planning Board (EPB)/Kementerian Perencanaan, sedangkan NITI Aayog (lembaga think tank India) merupakan transformasi dari Planning Comission.

\section{Tranformasi Lembaga Perencanaan dan Think tank Pemerintah di Korea dan India}

\subsection{Korea Development Institute}

Korea Development Institute (KDI) didirikan pada tahun 1971 di masa Pemerintahan Park Chung-hee. Ketika itu, Republik Korea merupakan salah satu negara paling miskin di dunia, dengan pendapatan per kapita sebesar USD 71 (peringkat 121 dari 125 negara) pada 1961.

Park Chung-hee memerintah selama hampir 4 periode yaitu sejak 19611979. Presiden Park merebut kekuasaan melalui kudeta militer kolektif yang menggulingkan presiden sebelumnya (Yun Bo Seon sebagai presiden Republik Korea II) pada tahun 1961. Park memerintah walaupun bukan sebagai pilihan utama para perwira militer ketika itu sampai pemilu dan pelantikan sebagai Presiden Republik Korea III pada tahun 1963. Pada masa pemerintahan Presiden Park pasang surut politik masih berlangsung, salah satunya pada tahun 1972, ketika Presiden Park mengumumkan darurat militer, membekukan konstitusi negara lalu membuat dirinya Presiden Seumur Hidup sambil sementara mengantarkan Republik Korea IV, dengan alasan adanya ancaman komunis yang secara konstan menggerogoti bangsa. Meskipun hidup dalam beberapa kali upaya pembunuhan, termasuk dua operasi oleh agen Korea Utara, Presiden Park akhirnya dibunuh pada tanggal 26 Oktober 1979 oleh kepala jasa keamanannya sendiri, setelah selama 18 tahun memimpin. Presiden yang terkenal otoriter inilah yang membawa Republik Korea meletakkan dasar-dasar pembangunan ekonominya.

Presiden Park banyak disebut memainkan peran penting dalam pengembangan Republik Korea yang pada periode itu disebut sebagai harimau ekonomi' dengan menggeser fokusnya dari negara agraria menjadi negara industrialisasi berorientasi ekspor. Ketika Presiden Park berkuasa pada tahun 1961, pendapatan per kapita Korea Selatan hanya USD 72 (peringkat 121 dari 125 negara). 
Presiden Park menciptakan lembaga pembangunan ekonomi, yakni: (1) Badan Perencanaan Ekonomi (EPB), (2) Departemen Perdagangan dan Industri (MTI), dan (3) Departemen Keuangan (MoF) yang bertanggung jawab untuk menyiapkan rancangan pembangunan ekonominya. Karena pentingnya EPB, kepala EPB ketika itu menjabat sekaligus sebagai deputi I Perdana Menteri. Kebijakan-kebijakan yang dituangkan oleh EPB dalam rencana lima tahunan ini bagi sebagian besar pihak banyak disebut menjadi tonggak bangkitnya ekonomi Korea. EPB yang mendorong kebijakan promosi ekspor berhasil mengangkat industri Korea menjadi maju dan meningkatkan kontribusi ekspor terhadap PDB menjadi 35 persen (1980-an), dibandingkan 5 persen (1950-an).

Secara singkat, performa Presiden Park dan dua kali lima-tahunan perencanaan EPB sebagai berikut: Republik Korea berhasil tumbuh lebih baik daripada masa pemerintahan sebelumnya, Presiden Rhee. Presiden Rhee gagal meningkatkan perekonomian Korea Selatan pasca terjadinya Perang Korea. Presiden Park pada pemerintahannya fokus untuk mengembangkan Kebijakan Industri Berbasis Ekspor. Kebijakan tersebut berhasil ditandai dengan meningkatnya kontribusi ekspor produk industri (terutama tekstil, sepatu dan apparel) terhadap PDB dan baiknya indikator keunggulan komparatif (comparative advantages). Kebijakan ini membuat Presiden Park sebenarnya memiliki kredit yang besar di mata masyarakat Korea Selatan dan Presiden Park memenangkan pemilu berikutnya pada tahun 1971 .

\section{Tentang KDI}

KDI telah jauh diakui sebagai institusi terkemuka think tank pemerintah dari Republik Korea dan berkontribusi pada kondisi sosial ekonomi dan pembangunan Republik Korea. Selama lebih dari tiga dekade, KDI secara konsisten menyediakan rekomendasi kebijakan (policy recommendation) dan petunjuk (guidance) berdasarkan analisis mengenai mendalam internasional maupun dalam negeri kondisi ekonomi dan melakukan proyeksi preventif dalam melakukan dan studi empiris. Studi empiris dalam membuat policy recommendation sangat diperlukan agar justifikasi dalam sebuah kebijakan publik dapat dipertanggung jawabkan secara akademik tidak berdasar keputusan politis semata.

Sementara menyadari pentingnya menemukan sumber pertumbuhan ekonomi baru untuk upaya pemulihan ekonomi yang keberlanjutan sewaktu terjadi krisis ekonomi global, KDI bekerja keras untuk menyusun Arah Kebijakan (policy directions) berdasarkan kebijakan yang komprehensif. Rancangan kebijakan tersebut telah melalui tahapan yang dapat dipertanggungjawabkan secara akademis dan melalui proses semacam tinjauan ulang sesama ilmuan dan ahli (peer-reviewed).

Dengan terus meningkatkan kapasitas penelitian dan kerjasama internasional, KDI akan menjadi bertaraf internasional yang: unggul dalam melakukan penelitian, dapat merumuskan kebijakan ekonomi preventif dan bisa dijalankan, dan pada saat yang sama memperkuat kapasitas komprehensif dalam melakukan studi akademis. Sejalan dengan penelitian yang dilakukan, KDI akan berusaha untuk terus-menerus melakukan diseminasi informasi mengenai isu-isu kebijakan ekonomi untuk pemangku kepentingan bidang ekonomi. 


\section{Produk KDI} antara lain:

Korean Development Institute bertanggung jawab untuk menyusun,

a. Membuat rancangan untuk Dokumen Perencanaan Tiga Tahunan (berjudul Three Years Innovation Plan) d/h. Dokumen Perencanaan Lima Tahunan yang dikeluarkan oleh MoSF.

b. Membuat penilaian terhadap dokumen pre-feasibility study (Pre-FS) yang dibuat oleh Kementerian sektoral.

c. Melakukan kajian sosial dalam bentuk Research Based Policy, contoh Economic Outlook.

d. Mengeluarkan buletin bulanan, contoh: KDI Economic Buletin. Monthly Economic Trends.

e. Menyelenggarakan konference internasional, contoh: KDI Journal of Economic Policy Conference.

Bahan-bahan tersebut disusun dan diserahkan kepada MoSF sebagai bahan masukan ketika MoSF mendesain program dan kegiatan. Tanggung-jawab pengambilan keputusan bukan merupakan kewenangan KDI, namun merupakan kewenangan MoSF. Dalam praktiknya, karena kredibilitas yang tinggi hasil assesment dan rekomendasi KDI hampir selalu ditindaklanjuti.

\section{Struktur Organisasi dan Hubungan Tanggung Jawab}

Di KDI terdapat total 360 peneliti dan 60 staf administrasi. Seluruhnya merupakan pegawai tetap di KDI yang statusnya adalah non-PNS. KDI juga bukan merupakan organ pemerintah. Sehingga hubungan antara KDI dan MoSF juga tidak sepenuhnya tergambarkan dalam dokumen resmi pemerintah Republik Korea.

Tanggung jawab pekerjaan dan pelaporan hasil pekerjaan dilakukan oleh KDI kepada MoSF langsung. Walaupun KDI bukan merupakan organ pemerintah, KDI menerima anggaran untuk melaksanakan pekerjaannya juga melalui MoSF.

Di dalam KDI, staf peneliti ditempatkan kedalam unit kerja yang disebut Departemen sesuai dengan bidang keahliannya. Saat ini terdapat tujuh departemen seperti yang ditunjukkan dalam gambar. Penentuan tujuh unit kerja tersebut disesuaikan dengan perkembangan zaman dan isu yang relevan dengan Republik Korea. Saat ini sudah tidak dijumpai unit kerja kemiskinan atau infrastruktur, karena Republik Korea sudah melalui tahapan tersebut. Saat ini Departement of Macroeconomic Policy, Departement of Financial Policy, dan Departement of Competition Policy merupakan tiga unit kerja yang utama. 


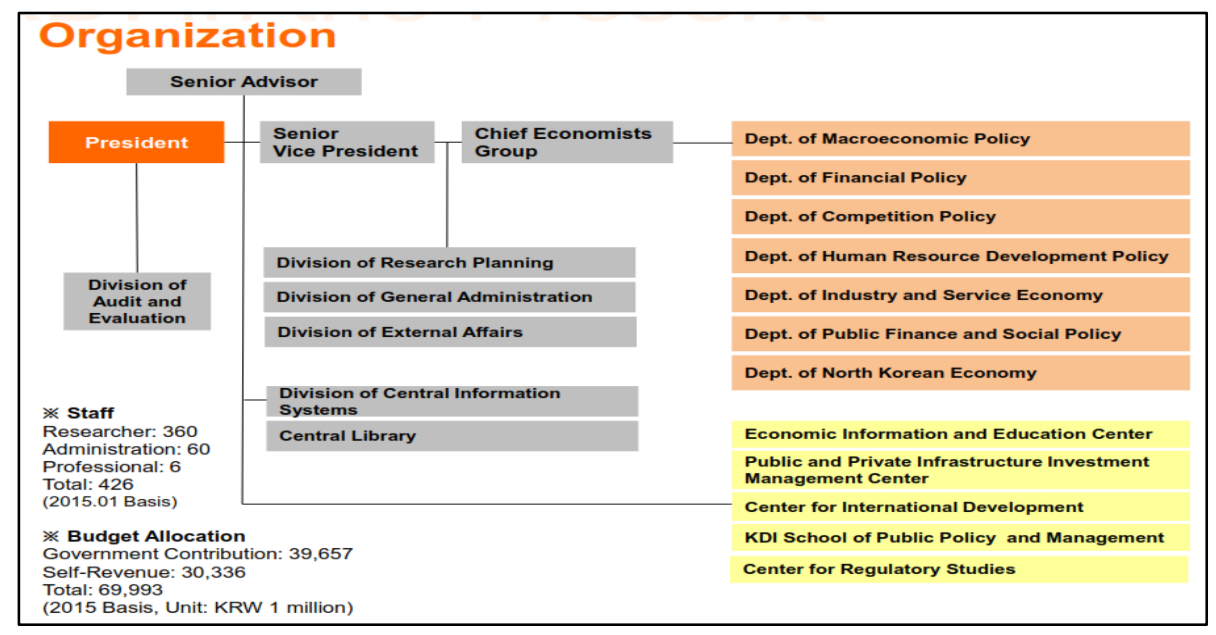

Gambar 1. Struktur Organisasi Korean Development Institute

Sumber: Laman KDI http://www.kdi.re.kr/kdi eng/

Selain unit kerja yang sifatnya struktural, KDI juga memiliki beberapa pusat untuk mendukung dan membantu para peneliti serta pihak eksternal untuk diseminasi dan peningkatan kapasitas, seperti Center for Education and Economic Information dan Public-Private Infrastructur Investment Management Center (PIMAC).

Beberapa catatan tentang perkembangan Korea dan peran KDI sebagai lembaga think tank pemerintah diuraikan sebagai berikut:

1. Republik Korea mampu tumbuh dari negara miskin di awal 1960-an (GDP perkapita \$71) menjadi salah satu negara paling maju di dunia dikarenakan transisi yang baik dari negara agrikultur menjadi negara industri. Kredit kepada pemerintah banyak disematkan bagi Presiden Park Chung-hee karena pada 18 tahun masa pemerintahannya kebijakan pemerintah mampu mendorong pertumbuhan ekonomi Korea Selatan dengan sangat tinggi dan dapat berkelanjutan. Peran nyata pemerintah dalam membuat perencanaan yang baik dalam hal ini sangat krusial.

2. Bentuk kelembagaan yang melakukan fungsi perencanaan dan anggaran seringkali berubah, sejak 1949 hingga 2015 terjadi beberapa kali perubahan bentuk yang terdiri atas Economic Planning Board (EPB, kemudian menjadi Ministry of Planning - MoP), Ministry of Finance (MoF), lalu KDI sendiri. Pada perkembangan terakhir di $2008 \mathrm{MoP}$ dan MoF digabung menjadi Ministry of Strategic and Finance (MoSF). Terlepas dari perubahan dan apapun lembaga yang berwenang untuk membuat perencanaan jangka panjang dan menengah hingga tahunan harus mampu mengambil kebijakan yang baik. Fungsi KDI adalah sebagai lembaga non-pemerintahan yang menjadi dewan pertimbangan profesional (advisory-body) untuk melakukan kajian sebagai landasan terciptanya budaya research based-policy. Research based-policy ini dilakukan untuk menjamin kualitas belanja pemerintah yang lebih baik, dan mengurangi risiko kegagalan proyek dan program.

3. Bentuk organisasi KDI yang disesuaikan dengan kondisi/isu kekinian dan rendahnya birokrasi yang terlibat dalam proses 'think tank' merupakan salah satu kunci diperolehnya kredibilitas yang dimiliki oleh KDI hingga saat ini. MoSF bertanggungjawab moral untuk menindaklanjuti rekomendasi KDI. 
Dalam kasus MoSF mengambil keputusan yang berlawanan dengan KDI, badan pemeriksa keuangan dan pembangunan dapat menanyakan argumentasi ilmiah dibalik diambilnya kebijakan tersebut.

\subsection{National Institution for Transforming India (NITI) Aayog}

Sejak awal Januari 2015, pemerintah India membentuk lembaga baru, lembaga think tank pemerintahan, dengan nama National Institution for Transforming India (NITI) Aayog. Lembaga baru ini menggantikan peran lembaga perencanaan pemerintah, Planning Commission, yang secara resmi dibubarkan di waktu yang sama. Dibubarkannya Planning Commission dan berdirinya NITI menandai era baru dalam pengambilan kebijakan pemerintah India, dari sistem perencanaan yang sepenuhnya diatur oleh negara menjadi perencanaan yang bersifat strategis dengan pendekatan ekonomi pasar.

Peran lembaga perencanaan yang kemudian digantikan oleh lembaga think tank pemerintahan juga terjadi di banyak negara. Namun kasus India adalah kasus terbaru. Proses transisi yang terjadi di India bisa menjadi pelajaran bagi Indonesia, lebih khusus Bappenas, dalam usaha untuk membentuk lembaga think tank pemerintahan. Terkait dengan itu, subbab ini akan membahas lebih dalam proses perubahan dari Planning Commission menjadi NITI Aayog: (1) faktor-faktor yang melatarbelakangi; (2) peran dan fungsi NITI Aayog dan perbedaan dengan Planning Commission; dan (3) permasalahan yang terjadi pada proses transisi.

\section{Perubahan dari Planning Commission ke NITI Aayog}

Planning Commission punya sejarah yang panjang dan peran yang cukup besar dalam proses pembangunan di India. Planning Commission, yang dibentuk pada tahun 1951 dan dipimpin pertama kali oleh Perdana Menteri Jawaharlal Nehru, merupakan tindak lanjut dari Resolusi Pemerintah India pada Maret 1950 yang menargetkan peningkatan standar hidup masyarakat melalui eksploitasi sumber daya yang efisien, peningkatan produksi dan kesempatan kerja bagi seluruh lapisan masyarakat. Melalui rencana pembangunan lima tahunan, Planning Commission bertanggung jawab menyusun rencana penggunaan sumber daya yang paling efektif dan seimbang dan menentukan prioritas pembangunan nasional. Sejak tahun 1951 hingga 2015, Planning Commission sudah menyusun dua belas (12) rencana pembangunan lima tahunan.

Dalam perjalanannya, peran Planning Commission mendapatkan berbagai sorotan, terutama seiring dengan perubahan sosio-ekonomi di masyarakat. Pendekatan perencanaan yang digunakan dalam Planning Commission adalah pendekatan yang dianggap sudah usang dan digunakan untuk era yang berbeda. Planning Commission dituntut untuk berevolusi, mencari peran baru yang lebih relevan dengan kondisi sosio-ekonomi masyarakat terkini dan supaya bisa lebih efektif dalam melakukan proses perencanaan di tengah berbagai reformasi ekonomi yang ada.

Namun hingga akhirnya dibubarkan, evolusi yang diharapkan tidak terjadi dan menjadi alasan utama di balik dibubarkannya Planning Commission dan digantikan oleh NITI Aayog. Dalam dokumen pembentukannya disebutkan bahwa NITI Aayog dilatarbelakangi perlunya paradigma baru dalam pemerintahan dimana 
peran pemerintah harus berevolusi dari sekadar mengalokasikan sumberdaya dalam sistem yang terpusat menjadi memberikan arahan strategis, mendukung, dan mengatur sistem yang lebih ke berbasis pasar. Dalam dokumen yang sama juga disebutkan bahwa pemerintah harus melakukan transisi dari pemain utama dalam ekonomi menjadi pendorong dan pembimbing yang dapat mendorong terciptanya semangat entrepreneurship dan berkembangnya sektor swasta, dari skala mikro hingga besar.

Perdana Menteri Narendra Modi dalam berbagai kesempatan menyampaikan bahwa ada tiga prinsip utama agenda pembangunan yang diusung oleh NITI Aayog, yakni pro-rakyat, proaktif, dan partisipatif. NITI Aayog diharapkan juga menjadi inkubator ide bagi pelaksanaan pemerintahan yang efektif. Secara resmi, tujuan dari NITI Aayog adalah mengembangkan visi ke depan prioritas, sektor, dan strategi pembangunan nasional dengan keterlibatan aktif dari pemerintah daerah. Untuk mencapai tujuan tersebut secara umum NITI Aayog melakukan beberapa hal berikut:

- Memberikan input dan arah strategis pada proses pengambilan kebijakan

- Mengembangkan mekanisme penyusunan rencana yang kredibel dimulai dari tingkat desa untuk kemudian diagregasi secara progresif ke tingkat pemerintahan yang lebih tinggi

- Memastikan kepentingan keamanan nasional sudah masuk dalam strategi dan kebijakan ekonomi

- Memberikan perhatian khusus pada kelompok masyarakat yang berisiko tidak menerima manfaat yang cukup dari kemajuan ekonomi

- Berkomitmen pada federalisme kooperatif melalui: (1) keterlibatan masyarakat secara aktif; (2) akses kesempatan yang sama bagi semua; (3) pemerintahan yang adaptif dan partisipatif; (4) penggunaan teknologi.

Digambarkan pada gambar xxx, untuk mencapai tujuannya, ada tiga fungsi utama yang diemban oleh NITI Aayog: (1) mendorong pluralisme dan desentralisasi; (2) think tank pemerintahan; dan (3) fasilitasi implementasi.

Dalam perkembangannya NITI Aayog juga dibebani tugas-tugas lainnya. NITI Aayog saat ini diharapkan untuk mengevaluasi efektivitas proyek-proyek yang didanani oleh World Bank. Selain itu, proyek-proyek besar harus mendapatkan persetujuan terlebih dahulu dari NITI Aayog. Salah satu contoh terbaru adalah pembangunan kereta cepat yang melalui persetujuan dari NITI Aayog.

Tabel 1. Perbedaan Planning Commission dan NITI Aayog

\begin{tabular}{|l|l|l|}
\hline & Planning Commission & NITI Aayog \\
\hline $\begin{array}{l}\text { Rencana } \\
\text { Pembangunan }\end{array}$ & $\begin{array}{l}\text { Merancang rencana } \\
\text { lima tahun nasional }\end{array}$ & $\begin{array}{l}\text { Mendesain agenda nasional } \\
\text { (strategic) }\end{array}$ \\
\hline Sifat Rencana & $\begin{array}{l}\text { Menetapkan kebijakan } \\
\text { nasional dan daerah } \\
\text { lengkap dengan alokasi } \\
\text { dananya }\end{array}$ & $\begin{array}{l}\text { NITI adalah lembaga think tank } \\
\text { (policy formulation } \text { hub) } \\
\text { kewenangan alokasi diberikan } \\
\text { kepada kementerian keuangan }\end{array}$ \\
\hline
\end{tabular}




\begin{tabular}{|l|l|l|}
\hline Ukuran Lembaga & $\begin{array}{l}\text { Relatif besar dangan } \\
\text { banyak anggota tetap }\end{array}$ & $\begin{array}{l}\text { Lebih kecil dengan banyak } \\
\text { anggota tentatif }\end{array}$ \\
\hline Peran Daerah & $\begin{array}{l}\text { Daerah tergabung } \\
\text { dalam National } \\
\text { Development Council }\end{array}$ & $\begin{array}{l}\text { Daerah tergabung dalam } \\
\text { Governing Council }\end{array}$ \\
\hline Pendekatan & Top Down & $\begin{array}{l}\text { Bottom Up (memfokuskan } \\
\text { pengamatan pada permasalahan } \\
\text { di tingkat lokal) }\end{array}$ \\
\hline
\end{tabular}

Tabel di atas menggambarkan perbedaan fungsi antara Planning Commission dengan NITI Aayog. Salah satu perbedaan yang paling nyata adalah jika Planning Commission memiliki budget power, NITI Aayog tidak. Dengan dibubarkannya Planning Commission, semua wewenang alokasi anggaran ada di bawah Kementerian Keuangan.

\section{Struktur Organisasi NITI Aayog}

Saat ini NITI Aayog dipimpin langsung oleh perdana menteri, dengan wakil ketua setingkat menteri. Anggota komite diisi oleh Menteri Keuangan, Menteri Dalam Negeri, Menteri Kereta Api, dan Menteri Pertanian. Anggota paruh waktu maksimum bisa diisi oleh dua orang dari institusi yang relevan. Governing Council berisikan kepala pemerintah daerah yang rutin mengadakan pertemuan untuk membahas berbagai permasalahan tingkat pusat dan daerah. Desain struktur dari governing council dan isu-isu yang dibahas hingga saat ini. Regional councils dibentuk sewaktu-waktu untuk menyelesaikan satu permasalahan atau isu yang berdampak kepada lebih dari satu daerah.

Struktur NITI Aayog akan dibentuk juga beberapa tim khusus:

- Research Wing: akan mengembangkan keahlian sektoral berisikan ahli, peneliti, spesialis, dan akademisi.

- Consultancy Wing: akan menyediakan dana dan keahlian bagi kebutuhan lembaga pemerintah pusat atau daerah.

- Team India Wing: beranggotakan perwakilan dari setiap daerah dan lembaga, dan akan menjadi tempat untuk melakukan kolaborasi di tingkat nasional. Tiap perwakilan akan memastikan setiap daerah dan lembaga memiliki suara di NITI Aayog dan membangun komunikasi langsung antar lembaga dan pemerintah daerah.

Aspek lain yang penting terkait struktur organisasi adalah sumber daya manusia (SDM) dalam NITI Aayog. Sebagaimana diungkapkan di atas, NITI Aayog diharapkan akan lebih ramping dari Planning Commission. Untuk SDM, hanya setengah dari SDM Planning Commision yang ditarik ke dalam NITI Aayog. Di luar itu NITI Aayog berusaha menarik SDM berbakat dari luar dengan menawarkan gaji 30 persen lebih tinggi dari posisi yang sama di Planning Commission. 


\section{Produk NITI Aayog}

Walau masih berusia singkat, tetapi sudah banyak produk yang dihasilkan oleh NITI Aayog. Salah satu yang paling sederhana adalah NITI Blogs dimana para anggota NITI menuliskan pemikiran mereka terkait perkembangan sosio-ekonomi terkini di masyarakat.

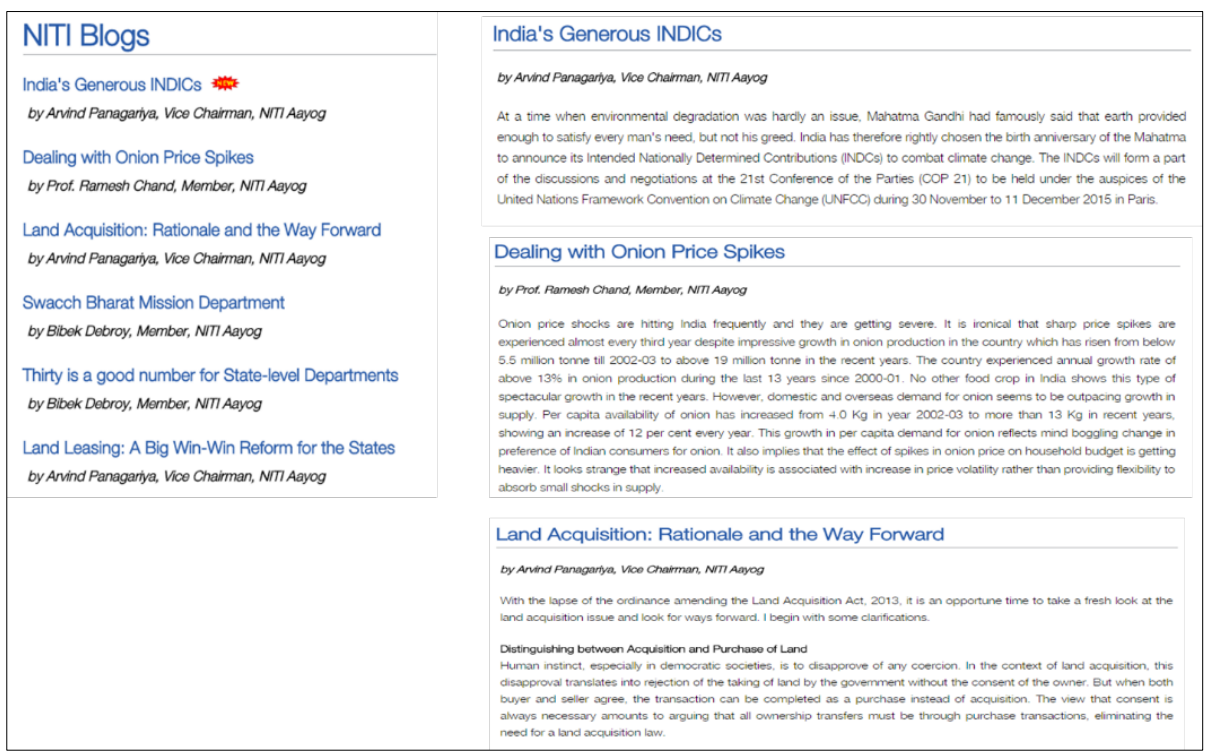

Gambar 2. Produk-produk NITI Aayog

Sumber: Laman resmi NITI Aayog

Berbagai policy/white paper juga telah dikeluarkan di antaranya:

1. Infrastructure: Powering Growth through Connectivity

2. Laporan tentang inovasi dan entrepreneurship

3. Laporan tentang pengembangan skill di India

4. Laporan tentang sanitasi (Swach Bharat Abhiyaan)

5. Laporan tentang sektor strategis industri

6. Skenario ketahanan energi hingga 2047

NITI Aayog juga melakukan beberapa inisiatif baru di antaranya:

1. Atal Innovation Mission: Platform untuk inovasi dan promosi yang melibatkan akademisi, enterprenuer, dan peneliti untuk mendorong budaya inovasi dan litbang di India. Platform ini juga digunakan untuk sebagai hub inovasi skala dunia bagi India.

2. Self Employment and Talent Utilization: Techno-financial, inkubasi, dan program fasilitasi untuk mendorong berbagai aspek bisnis start-up, terutama yang berbasis teknologi.

3. Consultation Paper untuk Undang-Undang Reformasi regulasi

\section{Adaptasi Fungsi Think tank dalam Perencanaan Pembangunan}

Sebagaimana KDI dan NITA Aayog, prinsip utama pembentukan lembaga think tank yang kredibel adalah perlunya independensi. Untuk menjadikan lembaga 
think tank yang mandiri tersebut perlunya posisi lembaga think tank yang mempunyai otoritas di dalam sistem organisasi Bappenas. Independensi dapat dibangun melalui mekanisme kerja, profesionalisme, serta kualitas kapasitas kerja yang kuat.

Dari hasil penelaahan praktik-praktik terbaik di atas, kajian ini mengerucut pada beberapa opsi posisi think tank yang fungsinya tergambar pada Gambar 1 berikut. Sedangkan alternatif pilihan kebijakannya sebagai berikut: (1) pemerintah dapat melakukan revitalisasi fungsi think tank di Bappenas, baik secara kualifikasi fungsi maupun penguatan kelembagaan; (2) membentuk lembaga baru di bawah Bappenas atau setingkat kementerian untuk mengemban fungsi sebagai jembatan antara ilmu pengetahuan dengan kebijakan.

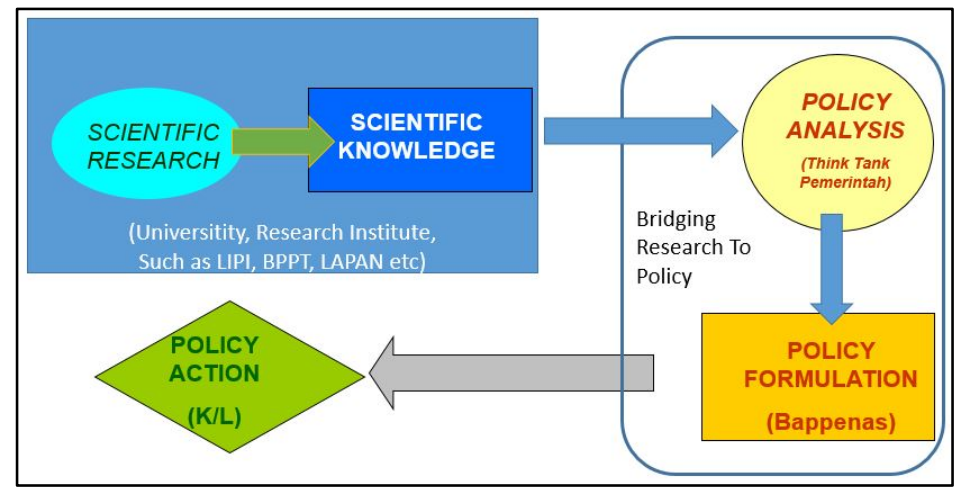

Gambar 3: Mekanisme 'bridging research to policy'

Sumber: Sofian Effendi (2014), dimodifikasi oleh Muhyiddin (2017).

Jika Pemerintah dalam melakukan revitalisasi fungsi think tank di Bappenas maka sisi positif yang akan terjadi mekanisasi yang otomatis 'bridging research to policy' dan 'bridging knowledge to power' dalam sebuah mekanisme internal di Bappenas. Dalam penyusunan dokumen-dokumen perencanaan yang teknokratik maka struktur ini sangat memudahkan dalam operasionalisasinya. Sisi negatif yang perlu dikedepankan adalah adanya kekhawatiran bahwa policy research kembali ditinggalkan karena lebih banyak mengandalkan expert judgment daripada rekomendasi dari policy research. Juga dikhawatirkan Bappenas terlalu berkutat dengan mekanisme penganggaran yang menyita rutinitas pekerjaan selama ini. Fungsi perencanaan dan penganggaran sudah sangat menguras waktu dan tenaga, sehingga pembentukan kelembagaan think tank yang masih embrio diperkirakan tidak dapat optimal.

Dalam bentuk opsi penguatan lembaga think tank, pemerintah dapat menerapkannya dengan spesifikasi tugas sebagaimana dalam referensi praktikpraktik terbaik yang meliputi: (1) Melakukan kajian kebijakan pembangunan nasional (termasuk quick response policy, studi evaluasi kebijakan pelaksanaan pembangunan); (2) Menformulasikan isu-isu strategis dan menyusun kerangka makro ekonomi; (3) Menyusun laporan perkembangan pelaksanaan RPJP, RPJMN, dan RKP secara berkala; (4) Menerbitkan jurnal dan buku riset analisa kebijakan; (5) Melakukan pembinaan fungsional peneliti kebijakan dan perencana. 
Kajian ini juga mengajukan beberapa saran langkah tindak-lanjut sebagai berikut: (1) Peningkatan kemampuan peneliti kebijakan dan perencana melalui pelatihan-pelatihan singkat dan magang di lembaga-lembaga pemikir di dalam negeri dan di luar negeri; (2) Peningkatan kerjasama riset dengan lembaga riset pemerintah dan non pemerintah di dalam negeri dan di luar negeri; (3) Penyusunan mekanisme kerja lembaga think tank, terutama yang berkaitan dengan instansi pemerintah sebagai pengguna; dan (4) Mengadakan berbagai upaya peningkatan kapasitas organisasi dan kualitas output.

\section{Fungsi Think Tank dalam Mekanisme Perencanaan dan Penganggaran Pemerintah}

Sejak terbitnya Undang-Undang No. 17 Tahun 2003 tentang "Keuangan Negara", maka praktis peran lembaga perencanaan seperti Bappenas tidak sepenuhnya bisa menyinergikan perencanaan program/kegiatan dengan perencanaan penganggaran ${ }^{2}$. Perencanaan dan penganggaran yang dilakukan oleh Bappenas hanya terbatas sampai alokasi anggaran indikatif, sedangkan alokasi definitifnya dilakukan oleh Kementerian Keuangan. Untuk detail kegiatan dan lokasi kegiatan sudah tidak dilakukan oleh Bappenas misalnya dalam perencanaan Dana Alokasi Khusus (DAK). Terkait DAK ini Kementerian Keuangan berkonsultasi dengan Badan Anggaran DPR untuk menentukan jumlah alokasi dan kabupaten yang mendapat DAK. Penentuan ini tidak dilakukan bersama Bappenas. Hal ini bertentangan dengan Putusan MK yang telah diterbitkan kemudian (Riyadi, 2014).

Penyatuan fungsi perencanaan tahunan terkait dengan koordinasi usulan program/kegiatan dari Kementerian/Lembaga dengan usulan penganggarannya sudah dilakukan di negara maju misalnya di Jepang. Kompilasi usulan program/kegiatan dari kementerian/lembaga diajukan dan dikoordinasikan oleh Kementerian Keuangan.

Selanjutnya oleh Kementerian Keuangan berdasarkan konsultasi dengan legislatif, disusun perencanaan program/kegiatan sekaligus alokasi anggarannya masing-masing. Jadi koordinasi rencana program/kegiatan dan anggaran serta belanja pemerintah dilakukan oleh satu kementerian yaitu Kementerian Keuangan. Semua ini dilakukan sebelum diajukan secara resmi oleh Perdana Menteri kepada Diet (DPR). Pengajuan draf RAPBN tersebut (yang disusun oleh Kemenkeu Jepang) sebelumnya telah disepakati terlebih dahulu oleh partai-partai politik. Dalam hal ini Kementerian Keuangan Jepang pada dasarnya berfungsi sepenuhnya sebagai koordinator penyusun perencanaan anggaran kementerian/ lembaga. Sehingga tidak terjadi duplikasi. Sedangkan kebijakan terkait industri dan perdagangan dilakukan oleh Ministry of Trade and Industry (MITI). Namun demikian proses perencanaan dan penganggaran oleh Kementerian Keuangan ini, arah kebijakannya (perencanaan dan penganggaran), harus mengacu pada Council of Economic and Fiscal Policy yang berada di kantor Perdana Menteri Jepang. Jadi terpisah antara penentu kebijakan dan perencanaan penganggarannya.

2 Sebab UU 17/2013 memang merupakan regulasi rumpun keuangan, yang memberikan otoritas penuh pada entitas organisasi pengelola keuangan ( Kementerian Keuangan) 
Di Indonesia, berdasarkan pelaksanaan perencanaan penganggaran tersebut di atas, maka pengalihan fungsi perencanaan RAPBN sepenuhnya dapat dilakukan oleh Kementerian Keuangan. Disamping melaksanakan fungsi-fungsi lain misalnya sebagai bendahara negara. Ini dapat mejadi salah satu alternatif demi efisiensi perencanaan program dan penganggaran. Pada praktiknya selama ini, meski telah diatur pembagian peran perencanaan tahunan yang disusun bersama Bappenas, tetapi ketidaksinkronan atas program dan kegiatan tetap terjadi.

Di Amerika Serikat, fungsi perencanaan dan penganggaran berada di kantor presiden, dikenal dengan Right Wing Office. Di kantor presiden Amerika ini terdapat Office of Management and Budget (OMB) yang berfungsi seperti Bappenas yaitu mengkoordinasikan usulan perencanaan program/ kegiatan kementerian/ lembaga. Namun demikian penyusunan rencana tersebut mendapat arahan dari Council of Economic Advicers yang juga berlokasi di Right Wing Office. Usulan perencanaan program dan kegiatan dari kementerian/ lembaga ini, setelah disusun oleh OMB, selanjutnya diajukan ke Senat dan akan dikaji oleh Budget Committee yang berada di Senat tersebut. Jadi Kementerian Keuangan di Amerika Serikat sepenuhnya berkonsentrasi sebagai bendahara negara (Department of Treasury).

Apabila mengacu pada pelaksanaan di Amerika Serikat tersebut di atas, maka Kementerian Keuangan sebagai bendahara negara dan berkonsentrasi meningkatkan pendapatan negara melalui Pajak, Bea Cukai dan pendapatan lain yang sangat diperlukan untuk pembangunan. Selama ini fungsi Kementerian Keuangan sebagai bendahara negara perlu ditingkatkan, terbukti dengan rasio Pajak terhadap APBN masih rendah dibandingkan negara-negara lain dan banyaknya dugaan kasus-kasus korupsi di Direktorat Jenderal Pajak. Namun demikian apabila Bappenas hanya akan berfungsi sebagai penentu arah kebijakan perencanaan RAPBN maka arah kebijakan ini digunakan sebagai dasar Kementerian Keuangan dalam menyusun RAPBN setiap tahun. Arah kebijakan ini ditentukan Bappenas agar konsisten dengan RPJMN, sehingga output perencanaan tahunan dapat mendukung dengan tepat outcome yang diharapkan dalam RPJMN.

\section{Perkembangan Think tank pada Pemerintahan Indonesia}

Bagaimana sebenarnya perkembangan lembaga think tank di Indonesia? Meskipun tidak secepat laju di negara-negara maju, McCawley (2014) menyampaikan pada sebuah lokakarya bahwa pada akhir-akhir ini, kelompok lembaga pemikir di Indonesia jauh lebih aktif daripada sebelumnya, dan makin banyak memberikan sumbangan pemikiran pada perdebatan kebijakan publik.

Sementara dalam sebuah lokakarya yang difasilitasi Inspirit Innovation Circles dan AusAID (Oktober 2012) terungkap pentingnya lembaga think tank dalam konteks kebijakan publik yang perlu didukung oleh kemampuan: (1) menyampaikan hasil penelitian dalam situasi kritis yang membutuhkan pengambilan keputusan secara cepat; (2) menemukan solusi-solusi dari permasalahan terkini; dan (3) membangun kredibilitas dan komunikasi efektif. Kesimpulan lainnya adalah bahwa selama ini kekuatan think tank Indonesia terletak pada sumber daya manusia yang semangat dan jaringan tank think dengan pemerintah, masyarakat, LSM dan perguruan tinggi. Pertanyaan selanjutnya adalah bagaimana peta lembaga yang bisa dikategorikan sebagai think tank Indonesia? 
Inventarisasi lembaga yang berkapasitas sebagai think tank di Indonesia sebenarnya pernah dilakukan pada tahun 2012, yang dilakukan secara spontan sehingga hasilnya belum memuaskan. Teridentifikasi bahwa think tank masih terbatas persyaratan membangun lembaga pelaksana studi dan pemikir, dengan isu yang bersifat wacana dan belum dapat ditransformasikan ke kebijakan. Di Indonesia, beberapa universitas juga sudah memiliki pusat-pusat studi tapi belum pernah dilakukan inventarisasi apakah termasuk kategori menjalankan fungsi dan peran sebagai lembaga think tank atau tidak. Pada kenyataannya, memang lembaga think tank yang berbasis universitas dan korporat sebenarnya sudah cukup banyak di Indonesia. Meskipun demikian inovasi yang muncul belum dapat diterjemahkan ke dalam kebijakan.

Sebagaimana lembaga-lembaga think tank pemerintah yang telah diuraikan dalam kajian ini, maka adanya kebutuhan kelembagaan think tank dapat mengacu pada referensi tersebut.

Bappenas, dalam sejarahnya mempunyai fungsi think tank yang melekat, namun kelembagaannya tidak berkembang, termasuk tidak adany unit kerja pada level eselon satu atau dua dengan fungsi khusus sebagai think tank pemerintah. Padahal, tantangan pembangunan yang semakin kompleks membuat kebutuhan akan adanya lembaga itu pasti menguat. Berkaca ke Korea dan India yang lembaga think tank-nya dari waktu ke waktu mengalami penguatan dan revitalisasi.

Pertama, pemerintah dapat melakukan revitalisasi sebagian organ di Bappenas untuk menjadi think tank. Sisi positifnya adalah terjadinya mekanisasi yang otomatis 'bridging research to policy' dan 'bridging knowledge to power' dalam sebuah mekanisme internal di Bappenas. Dalam penyusunan dokumen-dokumen perencanaan yang teknokratik maka struktur ini sangat memudahkan dalam operasionalisasinya. Sisi negatif yang perlu dikedepankan adalah adanya kekhawatiran bahwa policy research kembali ditinggalkan sebagaimana Bappenas selama ini melakukan penyusunan dokumen teknokratik yang lebih banyak mengandalkan expert judgment daripada rekomendasi dari policy research. Di samping itu Bappenas pada awalnya juga diamanatkan untuk membentuk kelembagaan think tank pemerintah, namun dalam perjalanannya tidak pernah dilakukan. Fungsi perencanaan dan penganggaran sudah sangat menguras waktu dan tenaga, sehingga pembentukan kelembagaan think tank yang masih embrio diperkirakan tidak dapat optimal.

Kedua, melepaskan organ think tank di Bappenas dan dijadikan lembaga khusus think tank di bawah Bappenas. Kelebihan dari opsi ini adalah kedekatan akses lembaga kepada pengambil keputusan tertinggi makin memudahkan mekanisme penyampaian rekomendasi kebijakan. Di samping itu sebagai anggota kabinet, lembaga think tank juga dapat berperan dalam setiap pengambilan keputusan. Kekurangannya adalah sebagai lembaga embrio, penempatan struktur yang tinggi dikhawatirkan dapat menjadi kontraproduktif. Besar kemungkinan terjadi ketidaksinkronan antara kualitas keluaran lembaga think tank dengan kebutuhan pengambilan keputusan.

Ketiga, membentuk kelembagaan baru think tank di bawah presiden dengan memanfaatkan sumber daya kelembagaan think tank yang sudah ada di pemerintahan 
seperti Bappenas dan Litbang Kementerian dan Lembaga yang sebelumnya juga mempunyai tugas sebagai jembatan atas ilmu pengetahuan kepada kebijakan (bridging knowledge to policy).

\section{VI.Kesimpulan dan Rekomendasi}

\subsection{Kesimpulan}

a. Perkembangan zaman menuntut sebuah pemerintahan yang harus dapat mengikuti kemajuan peradaban. Pemerintahan masa kini harus dapat memberikan manfaat lebih besar buat masyarakatnya melalui terobosanterobosan yang dihasilkan oleh ilmu pengetahuan. Salah satunya adalah tentang berfungsinya lembaga think tank pemerintah Indonesia yang berperan besar dalam mengakselerasi pembangunan sebuah negara.

b. Lembaga think tank pemerintahan pada dasarnya berfungsi sebagai jembatan antara ilmu pengetahuan dan kebijakan pemerintah. Kompleksitas permasalahan pembangunan menjadi tantangan pemerintah untuk dikelola dan diatasi berdasarkan ilmu pengetahuan yang bersumber dari penelitian akademis. Lembaga think tank harus dapat merumuskan bagaimana ilmu pengetahuan tersebut ditransformasikan menjadi riset kebijakan sehingga dihasilkan solusi kebijakan yang teruji.

\subsection{Rekomendasi}

a. Dalam struktur pemerintah pusat ada fungsi think tank pada Badan Perencanaan Pembangunan Nasional (Bappenas). Bappenas sebagai think tank cakupan tugasnya adalah meliputi fungsi pengkajian kebijakan di bidang perencanaan pembangunan, fasilitasi instansi pusat dan daerah, serta kerjasama dengan perguruan tinggi. Alat kelengkapan dasar sebagai lembaga think tank seperti fungsi penelitian kebijakan tidak dilakukan Bappenas, hal dasar yang sangat tertinggal. Menilik pada hal ini maka fungsi think tank di Bappenas perlu mendapat revitalisasi.

b. Dalam hal APBN, Bappenas hanya akan berfungsi sebagai penentu arah kebijakan perencanaan RAPBN yang dapat dicantumkan pada RPJMN. Kemudian arah kebijakan ini digunakan sebagai dasar Kementerian Keuangan dalam menyusun RAPBN setiap tahun. Arah kebijakan ini ditentukan Bappenas agar konsisten dengan RPJMN, sehingga output perencanaan tahunan dapat mendukung dengan tepat outcome yang diharapkan dalam RPJMN.

c. Untuk mewujudkannya ‘jembatan ilmu pengetahuan dan kebijakan' di Indonesia, maka Bappenas (juga pemerintah) dapat mempertimbangkan alternatif kelembagaan berikut:

- Melakukan revitalisasi sebagian organ di Bappenas untuk menjadi unit kerja think tank pemerintah. Opsi ini merujuk pada lembaga think tank di Thailand (NSEBD), dimana lembaga perencanaan dan penganggaran diperkuat oleh fungsi think tank.

- Menjadikan Bappenas sebagai lembaga think tank pemerintah secara keseluruhan, maka rujukannya adalah lembaga think tank pemerintah India (NITI Aayog).

- Membentuk lembaga khusus think tank di bawah Bappenas. Opsi ini merujuk pada lembaga think tank pemerintah Korea (KDI), dimana keberadaannya sebagai lembaga otonom yang mendukung lembaga perencanaan dan penganggaran. 
- Membentuk kelembagaan baru think tank di bawah presiden dengan memanfaatkan sumber daya kelembagaan think tank yang sudah ada di pemerintahan seperti Bappenas dan Litbang Kementerian dan Lembaga yang sebelumnya juga mempunyai tugas sebagai jembatan atas ilmu pengetahuan kepada kebijakan (bridging knowledge to policy). Opsi ini merujuk pada lembaga think tank pemerintah Australia (PC).

d. Alat kelengkapan yang lebih spesifik dari lembaga think tank pemerintah ini adalah: (1) melakukan riset dan penelitian kebijakan; (2) melakukan laporan berkala tentang perkembangan pelaksanaan program pemerintah dalam rencana strategis jangka panjang, menengah, dan pendek; dan (3) melakukan evaluasi implementasi kebijakan baik program maupun regulasi; (4) melakukan sinergi agar akumulasi ilmu pengetahuan dapat dijembatani dalam kebijakan pemerintah Indonesia.

\section{Daftar Pustaka}

Blondal, Jon R, Sang In-Kim, et al. 2006. Budgeting in Thailand, OECD Journal on Budgeting. OECD

Joong-Kyung Choi. 2013. Upside-Down Success Story of Korea's Economic Development. Daewon Publishing. Seoul (Korea).

Korea Institute for Industrial Economics \& Trade. 2013. A Specialized Think tank for Korean Industrial Economic Policy. Seoul (Korea).

McCarthy, Ibrahim, et al. 2010. Review of Social Science Capacity Building Support to Indonesia's Knowledge Sector. Knowledge Sector Initiative Report. AusAID. Jakarta (Indonesia).

Muhyiddin, Guspika, et al. 2017. The Institutional Study of Government Think tank. The Indonesian Journal of Development Planning Vol. I Issue 1-April 2017 p 76-92.

Muhyiddin, 2016. Menggagas Lembaga Think tank Pemerintah. Open editor opinion on Times Indonesia (timesindonesia.co.id), 18 November 2016.

Muhyiddin, Noor Arifin Muhammad, et al. 2014, Studi Model Hubungan Kerja Kelembagaan Think tank Pemerintah dengan Penentu Kebijakan. Tim Analisa Kebijakan. Bappenas. Jakarta (Indonesia).

Riyadi DMM, Guspika, Santoso B, Suhermanto H, Lukito PK, Haryanto, Yulius, Muhyiddin, Muhammad NA, Mulyo SA, Darmawijaya, et al. 2014. Reposisi Bappenas. Tim Analisa Kebijakan. Bappenas. Jakarta (Indonesia).

Riyadi DMM, Guspika, Santoso B, Suhermanto H, Lukito PK, Haryanto, Yulius, Muhyiddin, Muhammad NA, Mulyo SA, Darmawijaya, Nugroho H, et al. 2014. Think tank Bappenas: Sebuah Pemikiran. Tim Analisa Kebijakan. Bappenas. Jakarta (Indonesia).

Suryahadi, Asep, 2014, Konsep, Bentuk, Peran, Prospek, dan Tantangan Lembaga Think tank di Indonesia. SMERU Institute. Jakarta (Indonesia). 